\title{
In the peripheral blood mononuclear cells (PBMCs) of HCV infected patients the expression of STAT1 and IRF-1 is downregulated while that of caspase-3 upregulated
}

\author{
A. ALHETHEEL ${ }^{1,2}$, A. ALBARRAG ${ }^{1,2}$, A. HAKAMI ${ }^{1,2}$, Z. SHAKOOR $^{1,2}$, K. ALSWAT $^{1,3}$, \\ A. ABDO ${ }^{1,3}$, W. AL-HAMOUDI ${ }^{1,3}$, S. ALOMAR ${ }^{4}$
}

${ }^{1}$ King Khalid University Hospital, Riyadh, Saudi Arabia; ${ }^{2}$ Department of Pathology, College of Medicine, King Saud University, Riyadh, Saudi Arabia; ${ }^{3}$ Department of Medicine, College of Medicine, King Saud University, Riyadh, Saudi Arabia; ${ }^{4}$ Department of Zoology, College of Sciences, King Saud University, Riyadh, Saudi Arabia

Received May 24, 2019; revised October 7, 2019; accepted September 11, 2020

\begin{abstract}
Summary.-Several peripheral blood mononuclear cell (PBMC) defects have been linked with hepatitis $\mathrm{C}$ virus (HCV) infection, including alterations in cytokine secretion and increased cell death. This study was performed to investigate the expression levels of signal transducer and activator of transcription 1 (STAT1), interferon regulatory factor 1(IRF-1), and caspase 3 in PBMCs of patients infected with HCV.STAT1, IRF-1, and caspase 3 expression levels were compared in PBMCs from 19 untreated (naïve) HCV+ patients, 8 treated (sustained responder [SR]) HCV patients, and $20 \mathrm{HCV}$ - healthy controls. Moreover, PBMCs from naïve HCV + patients and SR-HCV patients were also evaluated for HCV RNA expression. The expression levels of STAT-1 and IRF-1 were significantly downregulated in PBMCs from naïve HCV + patients $(P<0.04)$ and SR-HCV patients $(P<0.05)$ compared to HCV-controls. In comparison with HCV- controls, naïve HCV+ and SR-HCV patients showed a significant upregulation in the expression of caspase-3 in their PBMCs $(P<0.0005$ and $P<0.03$, respectively). No significant differences were observed in the expression of STAT-1, IRF-1, and caspase-3 between PBMCs from naïve HCV + and SR-HCV patients. HCV RNA was detected in PBMCs from 18 (94.7\%) naïve HCV + patients as well as 6 (75\%) SR-HCV patients. Downregulation of STAT1 and IRF-1 expression levels and upregulation of caspase-3 expression level in PBMCs from HCV-infected patients may contribute to alterations in cytokine secretion and enhanced PBMCs cell death reported in previous studies.
\end{abstract}

Keywords: PBMC; hepatitis C virus; STAT1; IRF-1; caspase-3

\section{Introduction}

Hepatitis C infection is among most common viral infections worldwide (Modi and Liang, 2008). To date, more than 170 million individuals have been infected

E-mail: aalhetheel@ksu.edu.sa, abdulkarimfahad@hotmail. com; phone: +966-114671523.

Abbreviations: $\mathrm{HCV}=$ hepatitis $\mathrm{C}$ virus; $\mathrm{IFN}=$ interferon; $\mathrm{IL}=$ interleukin; IRF = interferon regulatory factor; $\mathrm{PBMC}=$ peripheral blood mononuclear cell; STAT = signal transducer and activator of transcription; SR-HCV = sustained responder-HCV with hepatitis $\mathrm{C}$ virus (HCV) and over 3 million new cases are reported every year. HCV infection causes acute and chronic liver inflammation, which in the majority of cases progresses to cirrhosis and hepatocellular carcinoma (Modi and Liang, 2008; Ashfaq et al., 2011). The virus infects and replicates in hepatocytes and other cell types, including peripheral blood mononuclear cells (PBMCs) and bone marrow cells (Darnell et al., 1994; Manzin et al., 1994; Bare, 2009; Revie and Salahuddin., 2011), resulting in persistence of infection and induction of chronic immune-activation. It has been recently shown that PBMCs from HCV + patients are sensitized to spontaneous programmed cell death and this phenomenon is associ- 
ated with reduced levels of interleukin (IL)-8, IL-6, and IL-10 production (Alhetheel et al., 2016). The molecular mechanism involved in these defects is still unclear.

Several studies have shown that PBMCs play a critical role in the elimination of pathogens via phagocytic and cytolytic activities. Many of such PBMC functions are mediated through the regulation of different signaling pathways, including the Janus kinase/signal transducer and activator of transcription (JAK-STAT) pathway (Darnell et al., 1994; Imada and Leonard, 2000; Levy and Darnell, 2002). HCV proteins such as the core and E2 polypeptides are capable to affect several signaling pathways including JAK-STAT, mitogen-associated protein kinase (MAPK), and phosphatidylinositol-3 kinase (PI3K) pathways in hepatocytes and macrophages. For instance, HCV core proteins have been shown to induce STAT3 and PI3K activation in monocytes and macrophages through the release of IL-6 (Tacke et al., 2011). Furthermore, several in vitro and ex vivo experiments have demonstrated that $\mathrm{HCV}$ and its proteins are capable of inducing apoptosis in hepatocytes and T cells (Bantel and Schulze-Osthoff, 2003). Thus, it is possible that HCV predisposes PBMCs to cell death and impairs their functions directly (by the action of its proteins) or indirectly (by induction of alterations in cytokine secretion via the STAT1 signaling pathway). Moreover, interferon gamma (IFN- $\gamma$ ) plays a critical role in HCV infection because of its anti-viral properties. A strong Th1 response, which is mediated by IFN- $\gamma$, plays a critical role in clearance of HCV infection (Saito and Gale, 2008). In addition, hyper-activation of interferon regulatory factor 1 (IRF-1) and elevated STAT1 have been implicated in enhancement of antiviral activity against HCV (Zhang XN et al., 2006). Considering the fact that a vast majority of studies have demonstrated the effect of HCV and its proteins on expression levels of STAT1 and IRF-1 using cell lines (Heim et al., 1999; Kanazawa et al., 2004), in this paper for the first time we describe the expression of STAT1, IRF-1 and caspase-3 in PBMCs from chronically infected HCV patients.

\section{Materials and Methods}

Patient characteristics. This is a cross-sectional study conducted at King Khalid University Hospital in Riyadh, Saudi Arabia, between November 2012 and December 2013. A total of 27 patients infected with HCV were enrolled. These included 19 (13 females and 6 males; mean age, $49 \pm 12.8$ years) untreated patients (naïve group) and 8 treated patients (three females and five males; mean age, $47 \pm 8$ years) (sustained responder [SR] group). The average HCV load in the naïve group was 1.35 $\times 10^{6} \pm 1.72 \times 10^{6} \mathrm{IU} / \mathrm{ml}$, while the SR-HCV group had undetectable levels of HCV for at least 6 months prior to the study. In addition, 20 healthy control individuals (all males; mean age, $32 \pm 10.6$ years) were included. They were negative by serology testing for infection with human immunodeficiency virus, human T-lymphotropic virus, and hepatitis B and $C$ viruses. The therapy of the SR-HCV group comprised the combination of PEGylated-IFN and ribavirin for 1 year. The study protocol was approved by the Institutional Review Board of the College of Medicine, King Saud University (Project\# E-11-461), and all patients provided written informed consent.

Isolation of PBMCs, RNA extraction, and real-time polymerase chain reaction (RT-PCR). PBMCs were isolated from whole blood by density gradient centrifugation, as previously described (Alhetheel et al., 2017). PBMCs were counted and $4 \times 10^{5}$ cells were cultured in Roswell Park Memorial Institute (RPMI)-1640 medium supplemented with $10 \%$ fetal bovine serum for $24 \mathrm{~h}$. The cells were washed and collected for RNA extraction. Total RNA was extracted from PBMCs using the RNeasy Mini kit (Qiagen, Hilden, Germany). Briefly, PBMCs $\left(5 \times 10^{5}\right.$ cells) were homogenized in a denaturation buffer containing guanidineisothiocyanate, which prevents RNA degradation. Cellular lysate was passed through genomic DNA eliminator spin column to purify RNA from genomic DNA. Equal volume of $70 \%$ ethanol was added to the total RNA to enhance its binding to the membrane of the RNeasy spin column during sample application, followed by two washes with a buffer containing ethanol. Total RNA was eluted with $50 \mu \mathrm{l}$ of RNase-free water. For the detection of HCV RNA from PBMCs, total RNA was

Table 1. Specific primers used in the study

\begin{tabular}{lll}
\hline Primers & Sequence & References \\
\hline HCV & Forward 5'-CGGGAGAGCCATAGTGGT-3' & Hideshima et al., 2007 \\
& Reverse 5'-CGCGACCCAACACTACTC-3' & \\
STAT-1 & Forward 5'-GGAACTTGATGGCCCTAAAGGA-3' & Kaiser et al., 2006 \\
& Reverse 5'-ACAGAGCCCACTATCCGAGACA-3' \\
IRF-1 & Forward 5'-GCATGAGACCCTGGCTAGAGAT-3' & \\
& Reverse 5'-CGGAACAAACAGGCATCCTT-3' & Kaiser et al., 2006 \\
Caspase-3 & Forward 5'-GCAGCAAACCTCAGGGAAAC-3' & \\
& Reverse 5'-TGTCGGCATACTGTTTCAGCA-3' & Hideshima et al., 2007 \\
GAPDH & Forward 5'-AATCCCATCACCATCTTCCA-3' & \\
& Reverse 5'-TGGACTCCACGACGTACTCA-3' & Imada and Leonard, 2000; \\
\hline
\end{tabular}


(a)

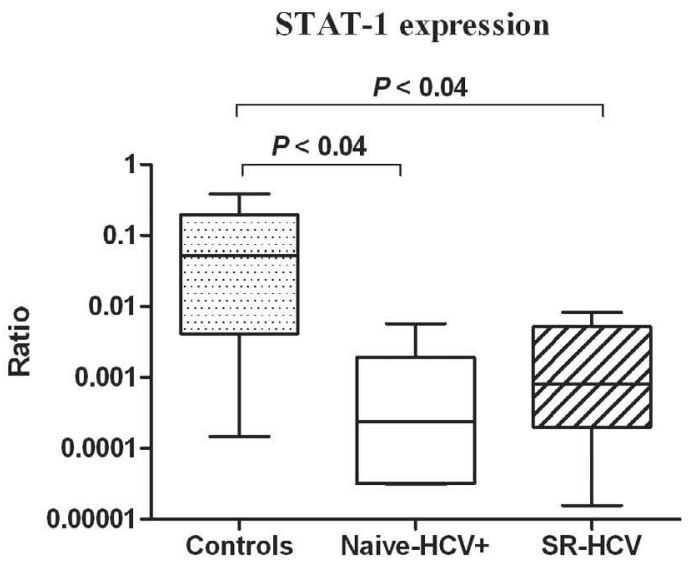

(b)

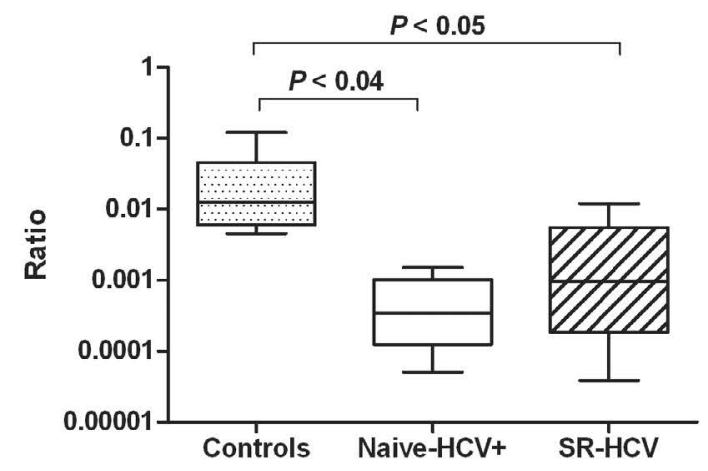

(c)

$$
\text { Caspase-3 expression }
$$

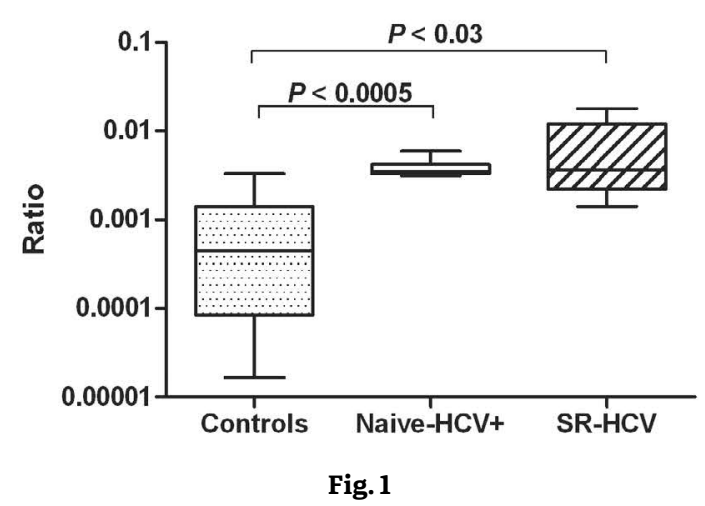

Expression levels of STAT1, IRF-1, and caspase-3 in PBMCs from study groups

Purified PBMCs $\left(4 \times 10^{5}\right.$ cells $)$ were cultured for $24 \mathrm{~h}$ and total RNA was extracted from the cells. The expression levels of STAT1, IRF-1, caspase-3, and GAPDH were measured using RT-PCR. The ratio of STAT1 (a), IRF-1 (b), and caspase-3 (c) expression levels for each patient group was plotted after normalization with GAPDH expression. All data were analyzed by Student's $t$-test. Significant differences are indicated with $P$ values. reverse-transcribed using the QuantiTect Reverse Transcriptase kit (Qiagen) according to the manufacturer's protocol. cDNA was amplified in the thermocycler T100 (Bio-Rad, Hercules, CA, USA) using HCV-specific primers indicated in Table 1, as per the previously described protocol (Hideshima et al., 2007). PCR amplicons were visualized on a 1.5\% agarose gel. The positive amplicons were sequenced using ABI 3730xl DNA Analyzer (Applied Biosystems, Foster City, CA, USA). For positive results, nucleotide sequences were blasted against NCBI database.

To evaluate the expression of STAT1, IRF-1, and caspase-3 genes, the cDNA was amplified using primers specific for STAT1, IRF-1, and caspase-3 along with the housekeeping gene encoding glyceraldehyde-3-phosphate (GAPDH) (Table 1) with Rotor Gene Q real-time PCR System (Qiagen), as previously described (Hideshima et al., 2007; Albertoni et al., 2012).

Hepatitis $C$ viral load in patients' sera was evaluated using the COBAS TaqMan analyzer and COBAS AmpliPrep/COBAS TaqMan HCV Quantities test v.2.0 (Roche Diagnostics, Manheim, Germany) as previously described (Alhetheel et al., 2016).

Statistical analyses. Data were analyzed using GraphPad Prism 5 software (GraphPad Inc., San Diego, CA). The non-paired t-test was used to evaluate the significance between different groups. A value of $P \leq 0.05$ was considered statistically significant.

\section{Results}

Expression levels of STAT1, IRF-1, and caspase-3 in PBMCs from study groups

We cultured PBMCs $\left(4 \times 10^{5}\right.$ cells $)$ from naïve $\mathrm{HCV}+\mathrm{pa}-$ tients, SR-HCV patients, and healthy controls for $24 \mathrm{~h}$. Cellular RNA was extracted and reverse-transcribed into cDNA. The expression levels of STAT1, IRF-1, and caspase-3 were measured by real-time PCR. The expression level of STAT1 was significantly downregulated in naïve $\mathrm{HCV}+$ patients $(P<0.04)$ and SR-HCV patients $(P<0.04)$ as compared with healthy controls (Fig. 1a). We found a similar significant downregulation in the expression level of IRF-1 in naive $\mathrm{HCV}+$ patients $(P<0.04)$ and SR-HCV patients $(P<0.05)$ as compared with healthy controls (Fig. 1b). On the other hand, the expression level of caspase-3 was significantly upregulated in naïve $\mathrm{HCV}+$ patients $(P<0.0005)$ and SRHCV patients $(P<0.03)$ as compared with healthy controls (Fig. 1c). No significant differences were observed in the expression levels of STAT1, IRF-1, and caspase-3 between PBMCs from naïve HCV + and SR-HCV patients (Fig. 1).

Detection of HCV RNA in PBMCs from naïve and SR-HCV patients

We cultured PBMCs $\left(4 \times 10^{5}\right.$ cells $)$ from naïve $\mathrm{HCV}+$ and SR-HCV patients for $24 \mathrm{~h}$. Cells were subjected to RNA 
Table 2. HCV-RNA in naïve and sustained responders HCV patients

\begin{tabular}{|c|c|c|c|c|c|}
\hline Study group & Patient \# & $\begin{array}{l}\text { HCV in serum } \\
(\mathrm{IU} / \mathrm{ml})\end{array}$ & $\mathrm{HCV}$ in PBMCs & Genotype & $\begin{array}{c}\text { Duration of HCV negativity } \\
\text { of serum }\end{array}$ \\
\hline \multirow[t]{19}{*}{ Naïve HCV patients } & P1 & 625762 & positive & 4 & 0 \\
\hline & $\mathrm{P} 2$ & 517632 & positive & 4 & 0 \\
\hline & P3 & 1091129 & positive & 4 & 0 \\
\hline & $\mathrm{P} 4$ & 1516317 & positive & 1 & 0 \\
\hline & P5 & 251634 & positive & 4 & 0 \\
\hline & P6 & 2100027 & positive & 1 & 0 \\
\hline & P7 & 1511113 & positive & 4 & 0 \\
\hline & $\mathrm{P} 8$ & 907450 & positive & $1 \mathrm{~b}$ & 0 \\
\hline & P9 & 380036 & positive & 1 & 0 \\
\hline & $\mathrm{P} 10$ & 318792 & positive & 4 & 0 \\
\hline & P11 & 200 & positive & $1 \& 4$ & 0 \\
\hline & $\mathrm{P} 12$ & 2052906 & negative & 2 & 0 \\
\hline & $\mathrm{P} 13$ & 179514 & positive & 4 & 0 \\
\hline & P14 & 685043 & positive & 1 & 0 \\
\hline & $\mathrm{P} 15$ & 4543161 & positive & 4 & 0 \\
\hline & $\mathrm{P} 16$ & 1988858 & positive & 4 & 0 \\
\hline & P17 & 191963 & positive & 4 & 0 \\
\hline & $\mathrm{P} 18$ & 24351 & positive & 4 & 0 \\
\hline & P19 & 6819886 & positive & 4 & 0 \\
\hline \multirow{8}{*}{$\begin{array}{l}\text { Sustained-responder } \\
\text { HCV patients }\end{array}$} & P20 & Not detected & negative & NA & 7 years \\
\hline & $\mathrm{P} 21$ & Not detected & positive & NA & 5 years \\
\hline & $\mathrm{P} 22$ & Not detected & positive & NA & 3 years \\
\hline & $\mathrm{P} 23$ & Not detected & positive & NA & 6 years \\
\hline & $\mathrm{P} 24$ & Not detected & positive & NA & 6 years \\
\hline & P25 & Not detected & positive & NA & 3 years \\
\hline & $\mathrm{P} 26$ & Not detected & positive & NA & 3 years \\
\hline & P27 & Not detected & negative & NA & 6 years \\
\hline
\end{tabular}

extraction and HCV RNA detection using PCR analysis. All treatment-naïve $\mathrm{HCV}$ + patients were detected positive for HCV RNA, with the serum viral load ranging from 200 to $6,819,886 \mathrm{IU} / \mathrm{ml}$. On the other hand, 18 treatment-naïve patients (94.7\%) were positive and one patient (5.3\%) was negative for HCV RNA in PBMCs (Table 2). No detectable HCV RNA expression was observed in serum samples from all SR-HCV patients; however, six SR-HCV patients (75\%) were positive and two patients (25\%) were negative for HCV RNA in PBMCs (Table 2). The detection of HCV in PBMCs was confirmed from the sequencing of PCR products.

\section{Discussion}

This study demonstrates that $94 \%$ of naïve HCV + patients and $75 \%$ of SR-HCV patients carry HCV RNA in their PBMCs. This observation is consistent with the findings of previously published data supporting the presence of HCV in the PBMCs of viremic and non-viremic individuals (Bronowicki et al., 1998; Cavalheiro et al., 2007; Mohamad et al., 2011). A number of other studies has also reported evidence not only for the presence of HCV in hematopoietic cells but also for the ability of the virus to replicate in these cell types (Lerat et al., 1998; Laskus et al., 2000; Castillo et al., 2005). On the contrary, there are sufficient published data refuting these claims. A study by Manzin et al. (1994) reported that PBMCs and bone marrow cells from all five naïve HCV patients tested negative for HCV RNA (Manzin et al., 1994). Another study investigating 69 non-viremic and 56 viremic individuals failed to document the presence of HCV RNA in PBMCs in all participants in question. Therefore, they proposed that PBMCs are unlikely reservoir for prolonged persistence of HCV infection (Bernardin et al., 2008). Similarly, a follow up study has reported that the PBMC-associated HCV RNA after treatment could possibly represent either viral particles non-specifically attached to blood cells or regarded the low-level replication of HCV in PBMCs as of 
minor quantitative importance for systemic replication (Kaiser et al., 2006). Despite the controversies, it has been proposed that the persistence of HCV infection in PBMCs as an extra-hepatic source of HCV infection remains a potent threat for reactivation of the virus after termination of successful anti-viral therapy (Pham et al., 2004; Radkowski et al., 2005).

Here we showed for the first time a significant downregulation in STAT1 and IRF-1 expression levels in PBMCs from treatment-naïve as well as SR-HCV patients. Several studies have demonstrated the effect of HCV and its proteins on expression levels of STAT1 and IRF-1 in human hepatocellular carcinoma (Huh7 cells) and other cells (Heim et al., 1999; Kanazawa et al., 2004; Lin et al 2005; Ciccaglione et al., 2007; Kumthip et al., 2012). On the contrary, a previous study demonstrated upregulated STAT1 expression in hepatocytes from chronic HCV patients with viremia (El-Saadany et al., 2013). STAT1 and IRF-1 are transcription factors involved in different immune functions and dysregulation in the expression of these proteins may compromise the immune system (Darnell et al., 1994; Imada and Leonard, 2000; Taniguchi et al., 2001; Levy and Darnell, 2002). IFN- $\alpha$ and IFN- $\gamma$ co-treatment in human hepatoma cells has been shown to upregulate the expression of STAT1 and IRF-1 that contributes to the enhanced interferon stimulated gene (ISG) expression with robust anti-viral activity (Zhang et al., 2006). Downregulation of STAT1 and IRF-1 expression in PBMCs of HCV patients observed in the present study is consistent with a previous report where HCV-transfected cell lines were shown to promote viral replication (Zhang et al., 2006). It is therefore possible that persistent HCV infection is most likely due to virus-induced suppression of IFN expression. Moreover, since interferon therapy upregulates expression of STAT1 and IRF-1, monitoring the expression of these two genes may serve as useful marker for assessing the therapeutic response.

We observed a significant upregulation in caspase-3 expression in PBMCs from treatment-naïve and SR-HCV patients. This observation is in line with the results of our previous study, wherein an increase in the spontaneous programmed cell death was observed in PBMCs from treatment-naïve and SR-HCV patients as compared to PBMCs from HCV- healthy controls (Alhetheel et al., 2017). Moreover, upregulation of caspase-3 has previously been shown to induce apoptosis in PBMCs among patients with high and low viral loads (Albertoni et al.,2012). In addition, a number of studies have already implicated caspase-3 in PBMCs dysfunction and death (Taniguchi et al., 2000; Nakamoto et al., 2002; Bantel and Schulze-Osthoff, 2003). Our study was limited by low patient numbers. Large scale follow-up studies are recommended to validate the findings of this study and to gain a better insight for un- derstanding of the PBMC dysfunction and increased cell death among patients with HCV infection.

\section{Conclusion}

Downregulation of STAT1 and IRF-1 expression levels and upregulation of caspase-3 expression level in PBMCs from HCV-infected patients may contribute to alterations in cytokine secretion and enhanced PBMCs cell death reported in previous studies.

Acknowledgments. The authors would like to thank the Faculty of Medicine, King Saud University; King Khalid University Hospital; and the Liver Center Research Institute for their collaboration and assistance in the recruitment of patients. The authors would also like to thank the Deanship of Scientific Research and RSSU at King Saud University for their technical support. This study was funded by King Abdulaziz City Science and Technology (grant No. P-C-11-0583).

\section{References}

Albertoni G, Arnoni CP, Latini FR, Andrade SS, Araújo PR, Rodrigues FK, Rozenchan PB, Mendes-Correa MC, Leite OH, Schor N, Girão MJ (2012): Altered of apoptotic markers of both extrinsic and intrinsic pathways induced by hepatitis $C$ virus infection in peripheral blood mononuclear cells. Virol. J. 9, 314. https://doi. org/10.1186/1743-422X-9-314

Alhetheel A, Albarrag A, Shakoor Z, Alswat K, Abdo A, Alhamoudi W (2016): Assessment of pro-inflammatory cytokines in sera of patients with hepatitis $C$ virus infection before and after anti-viral therapy. J. Infect. Dev. Ctries 10, 1093-1098. https://doi.org/10.3855/ jidc.7595

Alhetheel A, Albarrag A, Shakoor Z, Alswat K, Abdo A, AlHamoudi W, Alomar S (2017): Increased spontaneous programmed cell death is associated with impaired cytokine secretion in peripheral blood mononuclear cells from hepatitis $C$ virus positive patients. Viral Immunol.30,283-287. https://doi.org/10.1089/vim.2016.0166

Asano J, Nakano A, Oda A, Amou H, Hiasa M, Takeuchi K, Miki H, Nakamura S, Harada T, Fujii S, Kagawa K (2011): The serine/threonine kinase Pim-2 is a novel anti-apoptotic mediator in myeloma cells. Leukemia 25, 1182-1188. https://doi.org/10.1038/leu.2011.60

Ashfaq UA, Javed T, Rehman S, Nawaz Z, Riazuddin S (2011): An overview of HCV molecular biology, replication and immune responses. Virol. J. 8, 161. https://doi. org/10.1186/1743-422X-8-161

Bantel H, Schulze-Osthoff K (2003): Apoptosis in hepatitis C virus infection. Cell Death Differ. 10, 48-58. https:// doi.org/10.1038/sj.cdd.4401119 
Bare P (2009): Hepatitis C virus and peripheral blood mononuclear cell reservoirs. World J. Hepatol. 1, 67-71. https:// doi.org/10.4254/wjh.v1.i1.67

Bernardin F, Tobler L, Walsh I, Williams JD, Busch M, Delwart E (2008): Clearance of hepatitis C virus RNA from the peripheral blood mononuclear cells of blood donors who spontaneously or therapeutically control their plasma viremia. Hepatology 47, 1446-1452. https://doi. org/10.1002/hep.22184

Bronowicki JP, Loriot MA, Thiers V, Grignon Y, Zignego AL, Bréchot $C$ (1998): Hepatitis $C$ virus persistence in human hematopoietic cells injected into SCID mice. Hepatology 28, 211-218. https://doi.org/10.1002/hep.510280127

Castillo I, Rodriguez-Inigo E, Bartolome J, De Lucas S, OrtizMovilla N, Lopez-Alcorocho JM, Pardo M, Carreno V (2005): Hepatitis C virus replicates in peripheral blood mononuclear cells of patients with occult hepatitis C virus infection. Gut 54, 682-685. https:// doi.org/10.1136/gut.2004.057281

Cavalheiro Nde P, Filgueiras TC, Melo CE, Morimitsu SR, Araújo ES, Tengan FM, Barone AA (2007): Detection of HCV by PCR in serum and PBMC of patients with hepatitis C after treatment. Braz. J. Infect. Dis. 11, 471-474. https:// doi.org/10.1590/S1413-86702007000500006

Ciccaglione AR, Stellacci E, Marcantonio C, Muto V, Equestre M, Marsili G, Rapicetta M, Battistini A (2007): Repression of interferon regulatory factor 1 by hepatitis $C$ virus core protein results in inhibition of antiviral and immunomodulatory genes. J. Virol. 81, 202-214. https:// doi.org/10.1128/JVI.01011-06

Darnell JE Jr, Kerr IM, Stark GR (1994): Jak-STAT pathways and transcriptional activation in response to IFNs and other extracellular signaling proteins. Science 264, 1415-1421. https://doi.org/10.1126/science.8197455

El-Saadany S, Ziada DH, Bassat HE, Farrag W, El-Serogy H, Eid M, Abdallah M, Ghazy M, Salem HA (2013): The role of hepatic expression of STAT1, SOCS3 and PIAS1 in the response of chronic hepatitis $C$ patients to therapy. Can. J. Gastroenterol. 27, 13-17. https://doi. org/10.1155/2013/562765

Haseley A, Boone S, Wojton J, Yu L, Yoo JY, Yu J, Kurozumi K, Glorioso JC, Caligiuri MA, Kaur B (20125): Extracellular matrix protein CCN1 limits oncolytic efficacy in glioma. Cancer 72,1353-1362. https://doi.org/10.1158/00085472.CAN-11-2526

Heim MH, Moradpour D, Blum HE (1999): Expression of hepatitis $C$ virus proteins inhibits signal transduction through the Jak-STAT pathway. J. Virol. 73, 8469-8475. https://doi.org/10.1128/JVI.73.10.8469-8475.1999

Hideshima T, Catley L, Raje N, Chauhan D, Podar K, Mitsiades C, Tai YT, Vallet S, Kiziltepe T, Ocio E, Ikeda H (2007): Inhibition of Akt induces significant downregulation of survivin and cytotoxicity in human multiple myeloma cells. Br. J. Haematol. 138, 783-791. https://doi. org/10.1111/j.1365-2141.2007.06714.X

Imada K, Leonard WJ (2000): The Jak-STAT pathway. Mol. Immunol. 37, 1-11. https://doi.org/10.1016/S0161$\underline{5890(00) 00018-3}$
Kaiser P, Niederost B, Joos B, Wyl VV, Opravil M, Weber R, Günthard HF, Fischer M (2006): Equal amounts of intracellular and virion-enclosed hepatitis $C$ virus RNA are associated with peripheral-blood mononuclear cells in vivo. J. Infect. Dis. 194, 1713-1723. https://doi. org/10.1086/508431

Kanazawa N, Kurosaki M, Sakamoto N, Nakagawa M, Enomoto N, Tanabe Y, Koyama T, Maekawa S, Yamashiro T, Chen CH, Itsui Y (2004): Regulation of hepatitis C virus replication by interferon regulatory factor 1 . J. Virol. 78, 9713-9720. https://doi.org/10.1128/JVI.78.18.97139720.2004

Kumthip K, Chusri P, Jilg N, Zhao L, Fusco DN, Zhao H, Goto K, Cheng D, Schaefer EA, Zhang L, Pantip C (2012): Hepatitis C virus NS5A disrupts STAT1 phosphorylation and suppresses type I interferon signaling. J. Virol. 86, 8581-8591. https://doi.org/10.1128/JVI.00533-12

Laskus T, Radkowski M, Piasek A, Nowicki M, Horban A, Cianciara J, Rakela J (2000): Hepatitis C virus in lymphoid cells of patients coinfected with human immunodeficiency virus type 1 : evidence of active replication in monocytes macrophages and lymphocytes. J. Infect. Dis. 18, 442-448. https://doi.org/10.1086/315283

Lerat H, Rumin S, Habersetzer F, Berby F, Trabaud MA, Trépo C, Inchauspé $G$ (1998): In vivo tropism of hepatitis C virus genomic sequences in hematopoietic cells: influence of viral load, viral genotype, and cell phenotype. Blood 91,3841-3849. https://doi.org/10.1182/blood.V91.10.3841

Levy DE, Darnell JE Jr (2002): Stats: transcriptional control and biological impact. Nat. Rev. Mol. Cell. Biol. 3, 651-662. https://doi.org/10.1038/nrm909

Lin W, Choe WH, Hiasa Y, Kamegaya Y, Blackard JT, Schmidt EV, Chung RT (2005): Hepatitis C virus expression suppresses interferon signaling by degrading STAT1. Gastroenterology 128,1034-1041. https://doi.org/10.1053/i. gastro.2005.02.006

Manzin A, Candela M, Paolucci S, Caniglia ML, Gabrielli A, Clementi M (1994): Presence of hepatitis C virus (HCV) genomic RNA and viral replicative intermediates in bone marrow and peripheral blood mononuclear cells from HCV-infected patients. Clin. Diagn. Lab. Immunol.1,160-163. https://doi.org/10.1128/CDLI.1.2.160163.1994

Modi AA, Liang TJ (2008): Hepatitis C: a clinical review. Oral Dis. 14, 10-14. https://doi.org/10.1111/j.1601-0825. 2007.01419.x

Mohamad HI, El-Bab HK, Kamal AM (2011): HCV RNA in serum and peripheral blood mononuclear cells after successful interferon therapy. Hepatogastroenterology 58, 932-936.

Nakamoto Y, Kaneko S, Kobayashi K (2002): Increased susceptibility to apoptosis and attenuated Bcl-2 expression in $\mathrm{T}$ lymphocytes and monocytes from patients with advanced chronic hepatitis C. J. Leukoc. Biol.72, 49-55.

Radkowski M, Gallegos-Orozco JF, Jablonska J, Colby TV, Walewska-Zielecka B, Kubicka J, Wilkinson J, Adair D, Rakela J, Laskus T (2005): Persistence of hepatitis C virus in patients successfully treated for chronic hepa- 
titis C. Hepatology 41,106-114. https://doi.org/10.1002/ hep.20518

Revie D, Salahuddin SZ (2011): Human cell types important for hepatitis $C$ virus replication in vivo and in vitro: old assertions and current evidence. Virol.J.8,346. https:// doi.org/10.1186/1743-422X-8-346

Saito T, Gale M (2008): Regulation of innate immunity against hepatitis C virus infection. Hepatol. Res. 38, 115-122.

Pham TN, MacParland SA, Mulrooney PM, Cooksley H, Naoumov NV, Michalak TI (2004): Hepatitis C virus persistence after spontaneous or treatment-induced resolution of hepatitis C. J. Virol. 78, 5867-5874. https://doi. org/10.1128/JVI.78.11.5867-5874.2004

Tacke RS, Tosello-Trampont A, Nguyen V, Mullins DW, Hahn YS (2011): Extracellular hepatitis $C$ virus core protein activates STAT3 in human monocytes/macrophages/ dendritic cells via an IL-6 autocrine pathway. J. Biol.
Chem. 286, 10847-10855. https://doi.org/10.1074/jbc. M110.217653

Taniguchi T, Ogasawara K, Takaoka A, Tanaka N (2001): IRF family of transcription factors as regulators of host defense. Annu. Rev. Immunol.19, 623-655. https://doi. org/10.1146/annurev.immunol.19.1.623

Taniguchi T, Ogasawara K, Takaoka A, Taya N, Torimoto Y, Shindo M, Hirai K, Hasebe C, Kohgo Y (2000): Fasmediated apoptosis of peripheral blood mononuclear cells in patients with hepatitis C. Br. J. Haematol.110, 89-97.https://doi.org/10.1046/j.1365-2141.2000.01945.X

Zhang XN, Liu JX, Hu YW, Hu TW, Chen H, Yuan ZH (2006): Hyper-activated IRF-1 and STAT1 contribute to enhanced interferon stimulated gene (ISG) expression by interferon alpha and gamma co-treatment in human hepatoma cells. Biochim. Biophys. Acta 1759, 417-425. https://doi.org/10.1016/j.bbaexp.2006.08.003 